\title{
II. COMPARISON IN RHEUMATOID AND NORMAL SERA*
}

BY

\author{
J. R. E. FRASER AND J. F. MCCALL \\ From the University of Melbourne Department of Medicine, Royal Melbourne Hospital, Victoria, Australia
}

In a preliminary communication (Fraser and Catt, 1961), evidence was cited that serum from patients with active rheumatoid arthritis appeared to damage human synovial cells in primary culture. These observations were briefly described with the report of a simple method for synovial cell isolation.

We have since studied the same and other systems with the object of measuring the degree of cell injury rather than relying on a gross visual assessment. One of the methods mentioned in the above paper was further developed for the estimation of cytoplasmic spreading (McCall and Fraser, 1966a). However, the continued use of primary cultures for cytotoxic studies presented two difficulties. The cell preparation at that stage of our experience often produced an appreciable amount of cell damage, and it became obvious that any additional toxic effect would appear relatively less against a background of non-specific injury. Secondly, the irregular supply of material for primary culture and the time involved in choice and preparation of experimental sera restricted the number of studies. We decided, therefore, to study

* This study was made possible by grants from the Arthritis and Rheumatism Research Council for Great Britain and the Commonwealth, the National Health and Medical Research Council of Australia, and the Australian Rheumatism Council. synovial cells maintained by serial passage, to meet both these problems.

The present paper reports a comparison of the effects of sera from rheumatoid and normal subjects upon the cytoplasmic spreading of human synovial cells after subculture.

\section{Methods}

The rheumatoid subjects were carefully chosen. All fulfilled the criteria of "classical" rheumatoid arthritis (Ropes, Bennett, Cobb, Jacox, and Jessar, 1959), and the disease was clinically active. At the time of the study, none had received anti-inflammatory drugs other than salicylates in the previous month, and salicylate medication was stopped for 12 to 24 hours before collection of blood. The control subjects were normal individuals without apparent joint disease. Neither group had received infusions of blood or serum. Other pertinent data are shown in Table I.. Serum was rapidly prepared from the subjects after overnight fasting, stored in sealed vials at $-20^{\circ} \mathrm{C}$., and thawed rapidly at $37^{\circ} \mathrm{C}$. with gentle rotation when needed for experiments. Care was taken at all times to avoid denaturation of serum proteins. One-half of each specimen was heated at $56^{\circ} \mathrm{C}$. for 30 minutes, and the other was left in the native state. Synovial cells were prepared from stock cultures grown for less than 90 days, and cytoplasmic spreading was measured by the method described earlier (McCall and Fraser, 1966a). Each rheumatoid serum was compared

TABle I

CLINICAL DATA ON SUBJECTS TESTED

\begin{tabular}{|c|c|c|c|c|c|c|c|c|c|c|c|c|}
\hline \multirow{3}{*}{ Sera } & \multirow{3}{*}{$\begin{array}{c}\text { Subject } \\
\text { No. }\end{array}$} & \multirow{3}{*}{ Sex } & \multirow{3}{*}{$\begin{array}{c}\text { Age } \\
\text { (yrs) }\end{array}$} & \multirow{3}{*}{$\begin{array}{c}\text { Titre of } \\
\text { Rheumatoid } \\
\text { Factor* }\end{array}$} & \multirow{3}{*}{$\begin{array}{l}\text { Lupus } \\
\text { Erythematosus } \\
\text { Phenomenon }\end{array}$} & \multirow{3}{*}{$\begin{array}{c}\text { Erythrocyte } \\
\text { Sedimentation } \\
\text { Rate } \\
\text { (mm. in 1st hr) }\end{array}$} & \multicolumn{6}{|c|}{ Serum Proteins (g./100 ml.) } \\
\hline & & & & & & & \multirow{2}{*}{ Total } & \multirow{2}{*}{ Albumin } & \multicolumn{4}{|c|}{ Globulin } \\
\hline & & & & & & & & & $\alpha_{I}$ & $\alpha_{2}$ & $\beta$ & $\gamma$ \\
\hline \multirow[t]{2}{*}{ Rheumatoid } & $\begin{array}{l}1 \\
2 \\
3 \\
4 \\
5\end{array}$ & $\begin{array}{l}\mathbf{F} \\
\mathbf{M} \\
\mathbf{F} \\
\mathbf{M} \\
\mathbf{M}\end{array}$ & $\begin{array}{l}47 \\
47 \\
22 \\
46 \\
59\end{array}$ & $\begin{array}{l}2,048 \\
2,048 \\
1,024 \\
1,024 \\
1,024\end{array}$ & Negative & $\begin{array}{l}31 \\
60 \\
52 \\
33 \\
33\end{array}$ & $\begin{array}{l}6 \cdot 8 \\
7.6 \\
7 \cdot 2 \\
7 \cdot 3 \\
6 \cdot 9\end{array}$ & $\begin{array}{l}2 \cdot 7 \\
3 \cdot 0 \\
3 \cdot 4 \\
3 \cdot 4 \\
3 \cdot 2\end{array}$ & $\begin{array}{l}0.6 \\
0.5 \\
0.5 \\
0.3 \\
0.3\end{array}$ & $\begin{array}{l}1 \cdot 1 \\
1 \cdot 2 \\
0 \cdot 8 \\
0 \cdot 8 \\
0 \cdot 7\end{array}$ & $\begin{array}{l}0.8 \\
1.4 \\
0.7 \\
0.7 \\
1.0\end{array}$ & $\begin{array}{l}1 \cdot 6 \\
1.5 \\
1.8 \\
2 \cdot 1 \\
1.7\end{array}$ \\
\hline & Means & & & & & & $7 \cdot 16$ & $3 \cdot 14$ & 0.44 & 0.92 & 0.92 & $1 \cdot 74$ \\
\hline \multirow[t]{2}{*}{ Normal } & $\begin{array}{l}1 \\
2 \\
3 \\
4 \\
5\end{array}$ & $\begin{array}{c}\mathbf{M} \\
\mathbf{F} \\
\mathbf{M} \\
\mathbf{F} \\
\mathbf{M}\end{array}$ & $\begin{array}{l}19 \\
21 \\
35 \\
27 \\
38\end{array}$ & $<16$ & Negative & $\begin{array}{l}1 \\
8 \\
3 \\
1 \\
1\end{array}$ & $\begin{array}{l}6 \cdot 2 \\
6 \cdot 2 \\
6 \cdot 8 \\
6 \cdot 6 \\
6 \cdot 0\end{array}$ & $\begin{array}{l}3 \cdot 5 \\
3 \cdot 1 \\
4 \cdot 0 \\
4 \cdot 3 \\
3 \cdot 4\end{array}$ & $\begin{array}{l}0.4 \\
0.3 \\
0.2 \\
0.2 \\
0.3\end{array}$ & $\begin{array}{l}0.5 \\
0.9 \\
0.6 \\
0.5 \\
0.6\end{array}$ & $\begin{array}{l}0.7 \\
0.7 \\
0.8 \\
0.6 \\
0.7\end{array}$ & $\begin{array}{l}1 \cdot 1 \\
1 \cdot 3 \\
1 \cdot 2 \\
1.0 \\
1 \cdot 0\end{array}$ \\
\hline & Means & & & & & & $6 \cdot 36$ & $3 \cdot 66$ & 0.28 & 0.62 & $0 \cdot 72$ & $1 \cdot 12$ \\
\hline
\end{tabular}

* Alexander and de Forest (1954). 
simultaneously with a control serum in a final concentration of 50 per cent. in Medium 199.

\section{Results}

The behaviour of synovial cell spreading in the various preparations of serum is recorded in Table II, and the means are illustrated in the Figure (opposite).

In heat-inactivated preparations, there was no significant difference between the rheumatoid and normal sera despite some variation between experiments and within the pairs. However, both types of serum in the native state showed a highly significant inhibition of cell spreading in contrast with their paired heat-inactivated aliquots. Furthermore, the native rheumatoid sera showed a highly significant degree of inhibition in addition to that of the corresponding normal sera. Despite the inhibitio in native sera, there was a significant increase in the degree of cell spreading between 24 and 48 hours in all preparations.

\section{Discussion}

It is clear that repetition of this experimente design is unlikely to reveal anything beyond the definite conclusions which can be reached at th point. The behaviour of heat-inactivated serum is similar to that reported earlier (McCall and Frasec. 1966a). The outstanding result of the present study is the extent to which all ten sera in the native state inhibited cytoplasmic spreading. This bore no relation to the ABO blood group system. The removal of this effect by relatively mild heating, aniç

TABLE II

EFFECTS OF RHEUMATOID AND NORMAL SERA ON SYNOVIAL CELLS

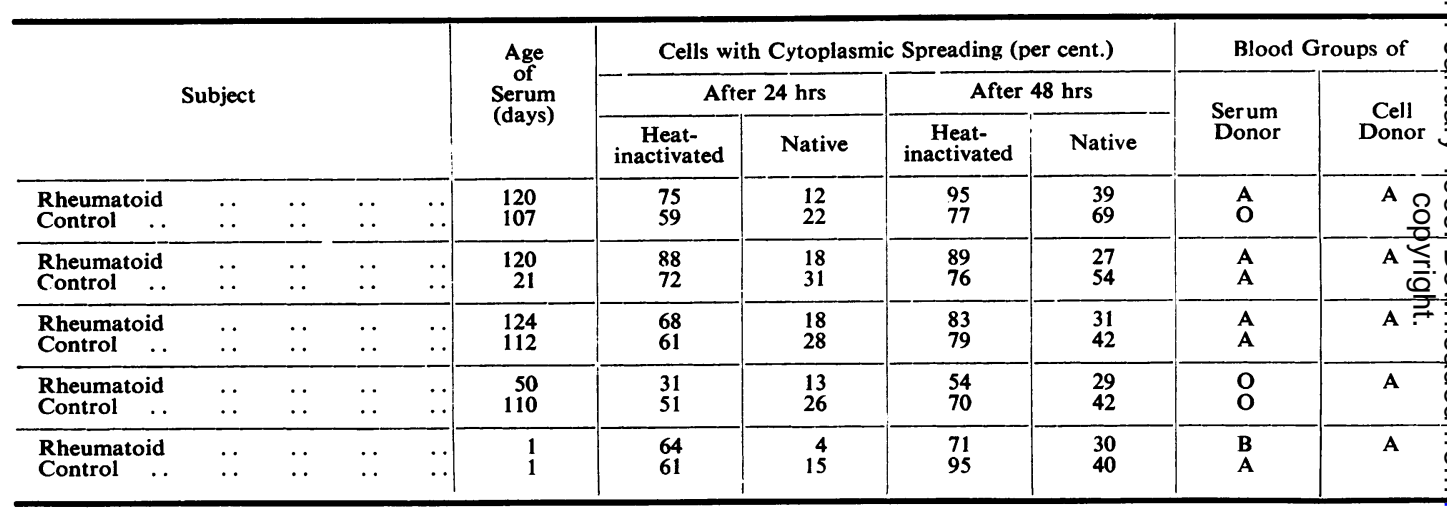

INTERACTION TABLES: TOTALS OF TRANSFORMED VALUES*

\begin{tabular}{c|c|c|c}
\hline \multirow{2}{*}{$\begin{array}{c}\text { Time } \\
\text { (hrs) }\end{array}$} & \multicolumn{2}{|c|}{ Type of Serum } & Total \\
\cline { 2 - 4 } & Rheumatoid & Control & \\
\hline 24 & $375 \cdot 3 a$ & $403 \cdot 9 a$ & $779 \cdot 2 b$ \\
\hline 48 & $487 \cdot 5 a$ & $542 \cdot 1 a$ & $1029 \cdot 6 b$ \\
\hline Total & $862 \cdot 8 b$ & $946 \cdot 0 b$ & $1808 \cdot 8$ \\
\hline
\end{tabular}

\begin{tabular}{l|c|c|c}
\hline $\begin{array}{c}\text { State } \\
\text { of } \\
\text { Serum }\end{array}$ & Type of Serum & Total \\
\cline { 2 - 3 } & Rheumatoid & Control & Fresh \\
Heat-inactivated & $\begin{array}{c}272 \cdot 6 a \\
590 \cdot 2 a\end{array}$ & $\begin{array}{r}370 \cdot 7 a \\
575 \cdot 3 a\end{array}$ & $\begin{array}{r}643 \cdot 3 b \\
1165 \cdot 5 b\end{array}$ \\
\hline Total & $862 \cdot 8 b$ & $946 \cdot 0 b$ & $1808 \cdot 8$ \\
\hline
\end{tabular}

Standard Errors

Treatment Totals $a($ of 10$)=21 \cdot 3$

Marginal Totals $b$ (of 20) $=30 \cdot 1$

To compare two treatment totals, significant differences

at 5 per cent. level $=59 \cdot 1$, and

at 1 per cent level $=77 \cdot 8$
* Derived from analysis of variance after angular transformatif (Fisher and Yates, 1953). 


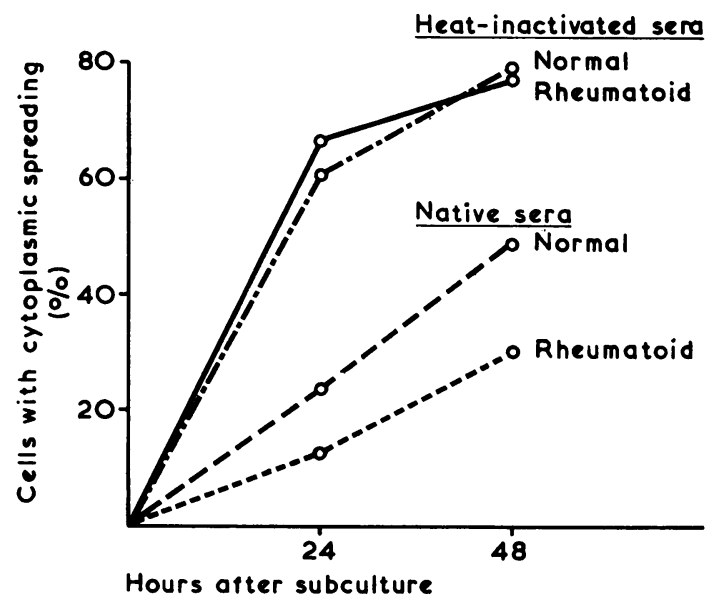

Figure-Percentage cells with cytoplasmic spreading in native and heat-inactivated rheumatoid and normal sera. Each point represents the mean of five observations.

the progressive recovery of spreading in the native sera, both suggest that a labile component of serum takes part in the inhibition. It is commonly recognized that fresh serum may occasionally exhibit toxicity in cell cultures, but we did not expect such a profound and consistent effect. It is possible that cells are most sensitive to injury in the suspended state after trypsin treatment, and it is intended to study comparable preparations of serum with synovial cells in a different phase of culture.

Inhibition of synovial cell spreading was undoubtedly greater in the native rheumatoid serum than in the normal. It is not likely that residual salicylate was responsible for this difference in view of the lability of the effect. However, it is impossible to say whether the difference represents an additional specific inhibitor or merely a higher content of that present in normal serum. The quantitative variations in serum protein fractions often observed in the disease (Table I), and the numerous other non-specific components found in rheumatoid serum such as necrotizing factor (Boake and Lovell, 1954) and immuno-conglutinin (Coombs, Coombs, and Ingram, 1961) would certainly support a similar explanation of the present findings. Although some trial studies indicated that it may be possible to choose a dilution in which only native rheumatoid serum exhibits inhibition relative to heat-inactivated serum, the question of specificity would still remain unanswered in the light of the present observations. This seems to require a different approach, such as fractionation of serum or use of a different cell system. However, the striking inhibitory effect of whole native serum found in this present study might well occur in other cell systems in vitro and could be relevant in vivo. Further studies of cell spreading in native serum is described in an accompanying paper (McCall and Fraser, 1966b).

\section{Summary}

The cytoplasmic spreading of human synovial cells has been studied in sera from rheumatoid and normal subjects. All sera tested, both normal and rheumatoid, exhibited in the native state a highly significant inhibition of synovial cell spreading. Inhibition of spreading was significantly greater in rheumatoid than in normal sera.

The significance of these findings is discussed.

We are indebted to Prof. E. J. Williams and Miss B. Laby for statistical analysis, to Prof. R. R. H. Lovell and Miss J. Ferguson for advice and criticism, and to Miss B. Nadudvary for technical assistance.

\section{REFERENCES}

Alexander R., and de Forest, G. K. (1954). Amer. J. Med., 16, 191.

Ropes, M. W., Bennett, Cobb, Jacox, and Jessar (1959). Ann. rheum. Dis., 18, 49.

Boake, W. C., and Lovell, R. R. H. (1954). Brit. J. exp Path., 35, 350.

Coombs, R. R. A., Coombs, A. M. and Ingram, D. G! (1961). "The Serology of Conglutination and itso Relation to Disease". Blackwell, Oxford.

Fisher, R. A., and Yates F. (1953). "Statistical Tables for Biological, Agricultural and Medical Research", 4th ed. Oliver and Boyd, Edinburgh. Fraser, J. R. E., and Catt, K. J. (1961). Lancet, 2, 1437. McCall, J. F., and Fraser, J. R. E. (1966a,b). Ann. rheum. Dis., 25, 42, 52.

\section{Comparaison des sérums rhumatoïdes et normaux}

\section{RÉSUMÉ}

On étudia l'expansion cytoplasmique des cellules synoviales dans les sérums des sujets rhumatoïdes et normaux. Tous les sérums étudiés, les rhumatoïdes et les normaux, accusèrent en leur état naturel un pouvoir inhibiteur significatif de l'expansion des cellules synoviales. Cette inhibition de l'expansion fut appréciablement plus accentuée dans le sérum rhumatoïde que dans le sérum normal

On discute la portée de ces résultats.

\section{Comparación de los sueros reumatoides y normales}

\section{SUMARIO}

Se estudió la expansión citoplásmica de las células sinoviales en los sueros de sujetos reumatoides y normales. Todos los sueros estudiados, tanto reumatoides como normales, acusaron en su estado natural un poder inhibidor significativo de la expansión de las células sinoviales. Esta inhibición fué significativamente más acentuada en el suero reumatoide que en el normal.

Se discute la importancia de estos resultados. 